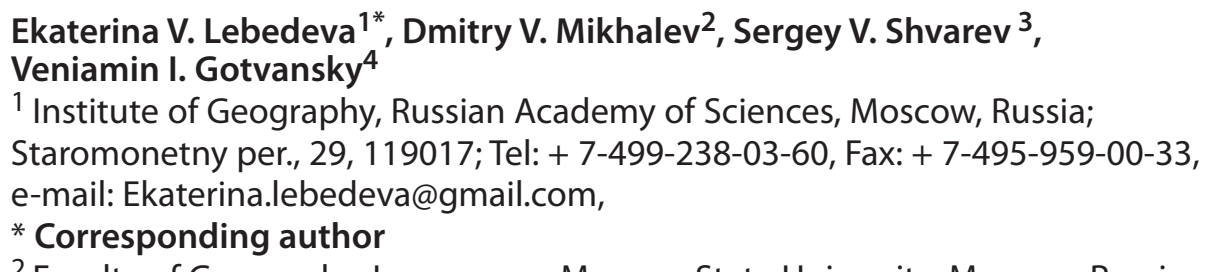

2 Faculty of Geography, Lomonosov Moscow State University, Moscow, Russia; Leninskie Gory, 1, 119991; Tel: + 7-495-939-25-26, e-mail: mikhalev.dmitry@gmail.com 3 Institute of Geography, Russian Academy of Sciences, Moscow, Russia; Staromonetny per., 29, 119017; Tel: + 7-499-238-03-60, Fax: + 7-495-959-00-33, e-mail: s.v.shvarev@gmail.com

4 Member of Russian Geographical Society, Moscow, Russia; 3th Vladimirskaya str., 4, fl. 37; Tel: + 7-926-137-29-96, e-mail: gotvanski@yandex.ru

\title{
TENSION OF GEOMORPHOLOGIC CONDITIONS IN THE MARGINAL MOUNTAIN BELTS OF THE PACIFIC RIM
}

\begin{abstract}
The maps of naturally determined geomorphologic tension, scale 1:8 million, for the territory of the Russian Far East and the central fragment of the mountain system of the Andes (between $5^{\circ} \mathrm{S}-19^{\circ} \mathrm{S}$ ) were compiled. We are using the term "tension" to define predisposition of the territory for the development of catastrophic processes. Tension was evaluated in nominal scores accordingly to the regional level of generalization. Assessment was based on the analysis of seismicity, amount of precipitation, the depth of the relief dissection and the spectrum of the dominant geomorphologic processes. The value of geomorphologic tension in the Russian Far East region ranges from 3 to 16 conventional points: in the Western Okhotsk Sea coast area it was estimated at 7-10 points, in the Sakhalin -10-12, in the Eastern Kamchatka - 13-15 and in separate Kuril Islands - 16 points. Thus, the study results confirmed the formerly stated supposition about the increase of nature-defined geomorphologic tension of the NW Pacific Ocean sector from the west to the east.
\end{abstract}

The zone of maximum potential development of catastrophic processes in the SE sector of the Pacific Rim is situated at the western mega slope of the Peruvian Andes between $9^{\circ} \mathrm{S}$ and $13^{\circ} 30^{\prime} \mathrm{S}$ and in the band width of $100 \mathrm{~km}$ along the Pacific coast. The geomorphologic tension of this area reaches $15-16$ points due to natural causes. The tension on the eastern mega slope of the Andes ranges from 9 to 12 points, except for some areas where it increases to 13-14; on the Altiplano it decreases to 6-10 points. An important feature of the study area is the asymmetric distribution of geomorphologic processes, so the geomorphologic tension, which significantly different at the oceanic and the inland (continental) slopes of the mountain chain. Comparison of data obtained for the two segments (NW and SE) of the Pacific Rim allows reaching a conclusion about the general regularities of the distribution of geomorphologic tension in the territory of marginal mountain belts around the Pacific Ocean with more confidence. The areas of potential catastrophic processes are located near the edge of the continent in either case.

KEY WORDS: geomorphologic tension, catastrophic processes, mapping, marginal mountain belts, the Far East, Andes 


\section{INTRODUCTION}

Research of dangerous and catastrophic relief forming processes has been underway for a long time, and the terms "hazard" and "risk" are widely applied in the geomorphology studies. However, in recent years the new terms have appeared: such as "susceptibility" to certain hazardous processes [Corominas, 2008] and geomorphic "tension" (or intensity) [Lebedeva, 2013a; Lebedeva, 2013b; Lebedeva et al., 2014b; Alizade, Tarikhazer, 2015; Lebedeva et al., 2015]. This allows for more precise determination of the areas which are potential subjects to various geomorphologic catastrophes.

Analysis of the distribution of natural disasters allows concluding that there are areas with more intensive development of catastrophic processes than others. The Russian Far East is one of them: here, according to statistics, the number of emergencies is approximately 2 times greater than the national average. We suggest to name the territories susceptible to catastrophic relief processes the zones of increased tension (or intensity) of geomorphologic processes or situation of increased geomorphologic tension [Gotvansky, Lebedeva, 2010; Lebedeva, 2013a, b; Lebedeva et al., 2014b]. The second definition seems to be more correct, since catastrophic processes in these areas are not constant, but the potential of its development, provided by certain forces-conditions, is real, and it materializes with certain probability of additional (in relation to average data) impact of these forces (seismic movements, anomalous hydrometeorological events and others).

Domination of relief features with high background velocities of morphogenesis is a typical situation for these territories, as long as processes which can sharply increase their spatial (volume, coverage, extension) and temporal (transmission rate, frequency and others) properties, in other words, which can develop catastrophically. In addition to the internal features (conditions) of catastrophic appearance (relief with potentially unstable properties, prone to different influences) acting in these regions it is necessary to have external forces, which cause the extreme character of the area's geomorphologic processes. Seismicity plays the key role among endogenous factors of intensity of contemporary geomorphologic processes in these regions. Among exogenous factors, the most important is the heavy rainfall which provokes a wide range of catastrophic processes. The cumulative effect of these factors greatly increases the probability of natural disasters.

G. Ananyev [Ananyev, 1998] linked the concept of intensity of geomorphologic processes with the balance of lithodynamic flows of the areas. He offered to calculate the value of the tension as the ratio of the maximum and the average volumes of transported material. Without denying the relevance of such calculations for sites where there are data of long-term stationary observations, we propose to analyze the parameters of relief and processes of morphogenesis in complex with endogenous and exogenous factors causing catastrophic development of geomorphic processes for areas where such data are not available.

The geomorphologic tension is defined by the authors as the readiness of geomorphologic system to pull out of the balanced condition and the danger of catastrophic processes developing under the action of external and/or internal forces, both natural and anthropogenic [Lebedeva, 2013, a, b].

Such zones of high geomorphologic tension are situated at the marginal continental mountainous systems of the Pacific Ocean with high parameters of tectonic, seismic and volcanic activity. Unstable state of geomorphologic systems and active reliefforming processes here are enhanced by deep and intensely dissected relief. Climatic factors (precipitation amount and character) also play a vital role. The anthropogenic activities occasionally promote natural processes and enforce the danger of local catastrophes. 
Our work is devoted to the north-western and south-eastern segments of the Pacific Ocean coast - the Russian Far East and the central part of the Andes mountain system. We set a goal to analyze specific features and regularities of distribution of the main factors that provoke catastrophic activation of geomorphologic processes and to find out zones of highest geomorphologic tension in these parts of the Pacific Rim as well. In this regard we mapped the geomorphologic tension of key segments.

The Russian Far East is the territory which exhibits extreme diversity of natural processes and phenomena including catastrophic. It can by clearly noted on the maps of current relief dynamics of North Eurasia [2003], of zoning of the territory of Russia to the degree of extreme ecologic-geomorphologic situation [Kozlova et al., 2005] and the map "The ecologic-geomorphologic hazard level of contemporary relief-forming processes" [2006]. The authors refer the major part of the Far East to the territories with the high rate of general ecologic-geomorphologic hazard, where several danger relief-forming processes with high index of intensity act simultaneously, and catastrophic occurrence of the certain processes are possible.

However, it is clear that there are very different areas - with more and less rate of catastrophic processes development. But these maps were compiled based on analysis of geomorphologic processes distribution, which (processes) contribute to formation or escalation of dangerous ecologic-geomorphologic situations, forced by anthropogenic impact, but without consideration of existing endogenous and exogenous forces that can provoke activation of these processes and considerably leverage the risk of natural disasters. Later, the author of one of these maps S.K. Gorelov wrote about necessity of working out the questions of endogenous factors of relief forming for the natural risk estimation [Gorelov, 2008]. Thus, for allocating the certain regions of increased geomorphologic processes intensity and forecasting possibility of its catastrophic development, additional data of seismic activity of the territory, precipitation distribution character, relief morphology and others were analyzed.

As far as SE sector of the Pacific Rim is concerned, the Andes are the world's most extended mountain system and one of the least explored. In 2007 under the international project, a group of experts from 7 countries, situated within the territory of Andes mountains, have compiled an integral map (scale 1:7500000) of the most disastrous consequences of natural processes and events [Conozcamos los peligros..., 2007]. The nineteen of such events during last 200 years were noted in territory of the Peruvian Andes. A more detailed research of the region has not been conducted yet despite its high relevance.

\section{RESEARCH METHODS}

A mapping method for geomorphologic tensity for a small-scale level (1:2.5-1:8 $\mathrm{mln})$ was described in detail by the authors early [Lebedeva, 2013b; Lebedeva et al., 2014b; Lebedeva et al., 2015]. It is based on analysis of the following characteristics: 1) complex of relief-forming processes of the territory and their ability to gain catastrophic character, 2) distinctions of relief morphology, which contribute to catastrophic development of relief-forming processes, 3) presence and zonality of demonstration of factors, which makes background processes extreme.

The authors tested 2 methods of assessing geomorphologic settings tensity for 2 Pacific coast segments. These methods are based on the same principles, but differ in the scheme of retrieval of factual material. However, the results were quite comparable. The methods require further improvement, but generally this approach to reconnaissance evaluation of territories is attractive. Moreover, it allows allocating the increased tension zones even within such poorly studied, in geomorphologic respect, mountainous systems as the Andes. 
Geomorphologic tension was assessed at the regional level of generalization and scale of the map: we used relative points based on the analysis of seismicity, precipitation quantity, features of relief and a spectrum of relief forming processes.

The leading complex of relief forming processes for the Russian Far East territory, their activity and areas of distribution are shown on the map "The ecologic-geomorphologic hazard level of contemporary relief-forming processes" [2006], which we had taken as the basis. There are 3 levels of hazard evaluation on this map: 1) high - several dangerous reliefforming forces with generally high intensity occur, 2) middle - variety of dangerous processes also occur, but with lower intensity, 3) low - narrow range of processes with low intensity.

Among relief morphology characteristics, which promote the development of catastrophic relief-forming processes, we placed special emphasis on the depth of erosion dissection and used the data of the map of "Erosion hazard of relief" [Timofeev, Bylinskaya, 1987]. Considerable depth of dissection is indicative of the higher intensity - e.g. potential possibility - of the vast variety of hazardous slope processes development - landslides, subsidences and others.

Seismic activity of territory plays the key role among factors, provoking the intensification of geomorphologic processes and increasing the dangerous situations risk. Even a small earthquake may cause many catastrophic processes: subsidences, landfalls, landslides, avalanches, mudslides, tsunami and others. We used the data from the seismic zoning map OSR-97 [Ulomov, 2013].

The overall quantity, type and intensity of precipitation influence the character and development of relief-forming processes of many regions. Coastal and intercontinental slopes often crucially differ in the marginal continental mountainous systems. Moreover, this difference may reach 500,
1000 and more mm of precipitation, which doubtlessly influence the trend and intensity of geomorphologic processes on slopes of different aspect. Numerical score may estimate the influence of this index.

In carrying out these small-scale cartographic works, evaluation of other factors proved to be problematic. We considered the presence of loose permafrost sediments mass only if the area of its spreading was really extensive and we can show places of influence of contemporary volcanic processes only by marking these active volcanoes with additional symbols.

The technique of geomorphic intensity mapping which was used for the Russian Far East has been adapted by us with the utilization of materials that existed for the territory of the central sector of the Andes. In this case, compilation process for the mapping was more complex than the same process for the Far East due to the absence of some basic maps that were available for the Russian territory. First of all, these include the map of "The ecologic-geomorphologic hazard level of contemporary relief-forming processes" [2006]. That is why the series of additional associated maps was compiled for the Central Andes segment: these are the maps of contemporary relief dynamics and dangerous and catastrophic processes; 16 types of regions with different ranges of prevailing catastrophic processes were determined [Lebedeva et al., 2014a]. This was the base for the final map of ecologicgeomorphologic hazard according to the methods developed by S.K. Gorelov [2008]. Three types of territories were isolated on the map: with high, middle and low rate of ecologic-geomorphologic danger.

Data of relief dissection deepness, available for the Russian part of the Pacific Rim according to the map of "Erosion hazard of relief" (1:2 500 000, IG RAN, [Timofeev, Bylinskaya, 1987]), were also absent for the Andes territory. Profiles of relief (cross-sections) were made to close this gap, using data of the global digital 
terrain model GTOPO 30 and digital data SRTM. The GTOPO 30 data, produced based on topographic maps distributed by the Earth Resources Observation and Science (EROS) Center [http://eros.usgs.gov], have spatial resolution of around $1 \mathrm{~km}$ and guarantee effective 3D-modeling for identification of regional relief characteristics in the study scales up to 1:1000000. A more detailed relief structure research, particularly evaluation of its characteristics, such as dissection depth, is based on the satellite radar data SRTM with spatial resolution of around $90 \mathrm{~m}$ and absolute altitude evaluation precision of around $20 \mathrm{~m}$, and allows differentiating relief elements with amplitude of up to the first meters. The depth of dissection was evaluated for squares with the sides of 20 $\mathrm{km}$ and profiles 200-300 km long. Thus we found the dissection depth for every surface segment, approximately $400 \mathrm{~km}^{2}$ in size, which is comparable to the data of "Erosion hazard of relief" map that we have used for the Far East.

For seismic zoning we used the Global Seismic Hazard Assessment Program (GSHAP) data. A probabilistic map of seismic hazard, obtained from the GFZ German Research Centre for Geosciences [http://gmo.gfzpotsdam.de], is represented with the data on ground acceleration, which can be exceeded during 50 years with $10 \%$ probability, which corresponds with the following frequency period of such a seismic impact - 1 time in 500 (475 is more correct) years (the Russian analogue is the map "A» OSR-97). Revaluation of the GSHAP data on a 12-point intensity scale, which is used in Russian seismic zoning, is made using normative correlations.

Evaluation of the annual precipitation of this territory is based on the South American map of precipitation, compiled from climatic and weather data, handled, archived and distributed by the Earth System Research Laboratory of the National Oceanic and Atmospheric Administration, USA [http:// www.esrl.noaa.gov]. The map represents the averaged data of annual precipitation for the period 1976-2009 years in a spatial grid with 2.50 mesh.

It should be pointed out that the most large scale geomorphologic disasters of the region are distinguished by overlapping and interconnecting the number of extreme processes. Thus, in that case we consider acceptable to add data on the magnitude of the studied characteristics, relevant increasing action of external agents, provoking catastrophic processes, or showing the morphosystem inner characteristics specificity (geomorphologic circumstances), also leading to increasing exogenous processes intensification. However, because of the different dimension and magnitude of the studied characteristics, the straight addition is not correct; thus, we, according to [Simonov, 1997; Liang at al., 2012], conducted "normalization" of the values by formula $X^{\prime}=(X$ $\left.-X_{\min }\right):\left(X_{\max }-X_{\min }\right)$, where $X$ is the real value of the characteristic, $X_{\max }-X_{\min }$ is the range of its possible values, and $X^{\prime}$ - the normalized characteristic's value within the interval from 0 to 1. Also, for calculation convenience [Liang at al., 2012] we converted the fraction values into the whole values, and considered them as the relative tension points. Moreover, due to the regional nature of our research, we analyzed not the characteristics' particular values, but their specific intervals.

Thus, for the estimation of more important, in our opinion, factors - seismicity and precipitation - we used a 10-point scale. However, this approach is not flexible to to accommodate every characteristic. Thus, the scale of conducted mapping does not allow us to show in details the true relief dissection depth and requires specific generalization. Moreover, although tension increase (susceptibility to catastrophic processes) does not depend on dissection depth, but beginning from certain values it does not grow at the same rate, as, for example, after quakes intensity increases. In turn, the ecologicgeomorphologic hazard level of the territory (the range of dominating relief forming processes) is the qualitative characteristic and 
Table 1. Interrelation of points and ranges of values of the main factors of geomorphologic tension

\begin{tabular}{|c|c|c|}
\hline Factors & Ranges of values & Points \\
\hline \multirow{6}{*}{ Seismicity (intensity of shocks), points } & $\mathrm{VI}-\mathrm{VII}$ & 1 \\
\hline & VII-VIII & 2 \\
\hline & VIII-IX & 4 \\
\hline & $I X-X$ & 6 \\
\hline & $X-X \mid$ & 8 \\
\hline & $>X I$ & 10 \\
\hline \multirow{4}{*}{ Precipitation quantity, mm per year } & $500-1000$ & 1 \\
\hline & $1000-1500$ & 2 \\
\hline & $\ldots$ & $\ldots$ \\
\hline & $>5000$ & 10 \\
\hline \multirow{3}{*}{ Erosion dissection depth, $\mathrm{m}$} & $400-800$ & 1 \\
\hline & $800-1600$ & 2 \\
\hline & $>1600$ & 3 \\
\hline \multirow{3}{*}{ Ecological-geomorphologic hazard } & Low & 1 \\
\hline & Middle & 2 \\
\hline & High & 3 \\
\hline
\end{tabular}

is noted for some subjectivity. As the result, in both cases, when grading this index, we had to prefer the expert evaluation and use the less fractionary scale with the maximum value of 3 points. Interrelations of the relative points and input value intervals of tension forces are shown in Table 1.

We understand that such an approach is quite conventional, and relies on expert assessment, but in case of this small-scale mapping it is the most correct method. This has been supported by our attempts of using a single (10 or 3) scale for all indicators. Actually, in the case of a single scale for all indicators, correction factors introduced usually are also based on expert assessment, as we see, for example, in [Bolysov et al., 2015].

All of these allowed us to obtain the so-called semi-quantitative reconnaissance evaluation, which, in its turn, allows comparing certain regions and isolating the zones of increased geomorphologic tension, i.e., sites with the maximum rates of characteristics, promoting intensification of morpholithogenesis processes.

\section{DISCUSSION}

Preliminary analysis of the natural preconditions of the geomorphologic tension in the Russian Far East [Gotvansky, Lebedeva, 2010] suggests increase of the tension towards the Pacific Ocean due to increase of impact of endogenous and exogenous factors, the features of contemporary tectonics and volcanism, of moisture of air masses and of the proximity of the main basis of denudation - the ocean level. Maps of naturally determined geomorphologic tension of processes (scale 1:2500000 and 1:8000000) were compiled firstly for the key parts of the Russian Far East - Kamchatka, Sakhalin and the Western Okhotsk region. These territories vary on geodynamic processes, landscape-climatic conditions and character of modern geomorphologic processes, and are indicative of differentiated estimation of geomorphologic tension. This allowed us to clarify and correct the method. For the key areas we also defined the territories under intense anthropogenic impact (the result of construction and mining). However, on the integral map of the Russian Far East (scale 1:8000 000) (Fig. 1) we had to limit our efforts 


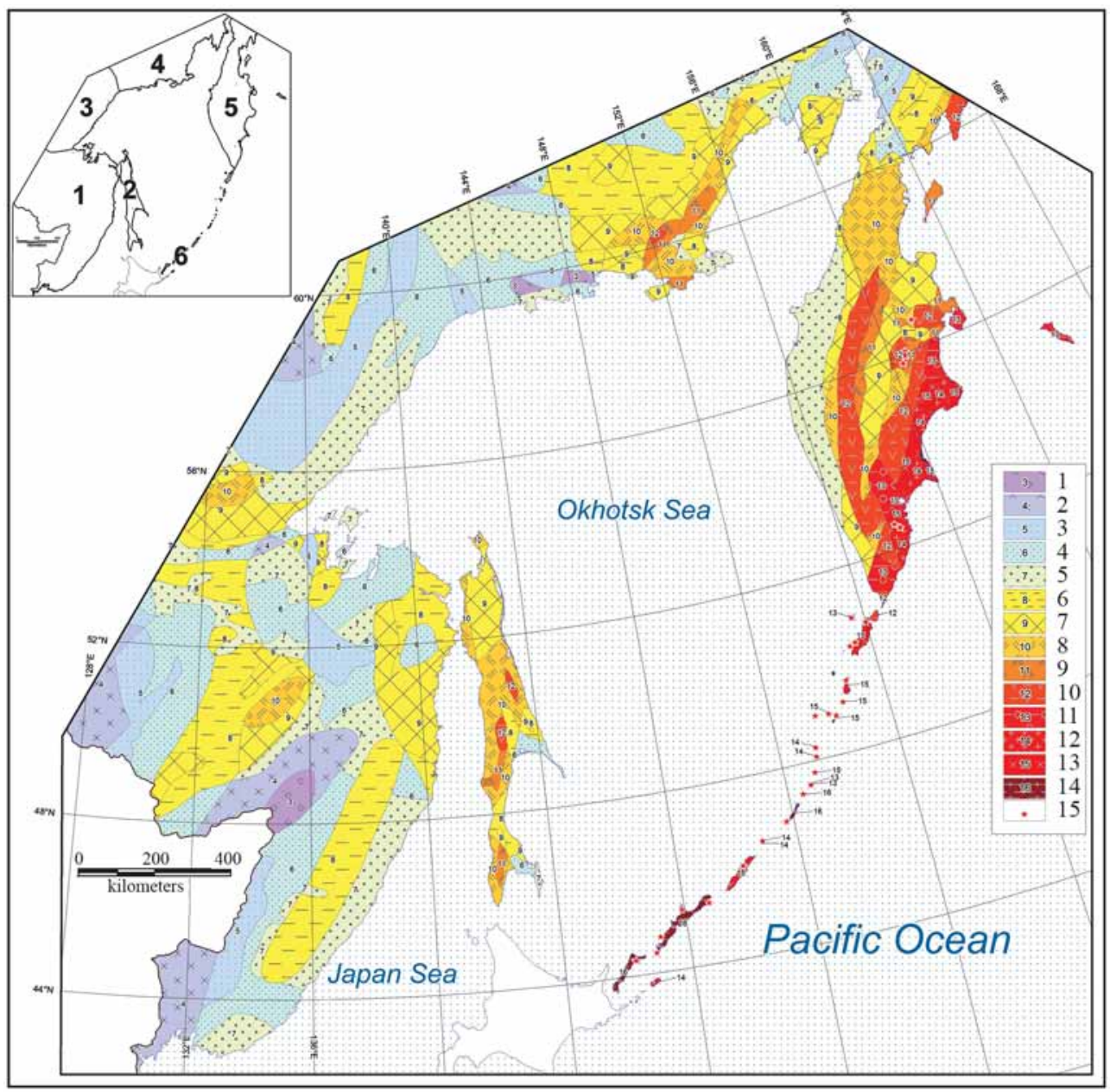

Fig. 1. Map of geomorphologic tension of the Russian Far East, scale 1:8000000. Legend:

1-14 - naturally determined geomorphologic tension (in points), 15 - active volcanoes.

On inset: regions: 1 - Primorye and Amur River Region; 2 - Sakhalin; 3 - Western Okhotsk Sea coast region, 4 - Northern Okhotsk Sea coast region; 5 - Kamchatka, 6 - Kuril Islands

to only naturally determined tension of the processes.

In the mainland of the Russian Far East, the naturally determined tension of geomorphologic conditions generally ranges from 3 to 10 points. For the Stanovoy ranges' roof-block uplift (the activated margin of the Aldanian shield with traces of late Pliocene volcanic activity) the deep dissection (up to $1000 \mathrm{~m}$ ), seismic activity of up to 8 points and a wide range of dangerous geomorphologic processes are characteristic. Near interstream areas, seismogenic splits are exist and there are many traces of seismic landslides. The total tension of Tokinsky Stanovik is 10 points. The Badzhalsky range, located at the junction of the Bureinsky platform massive and the Sikhote-Alin folded region, also belongs to a 8-point earthquakes zone. Seismic landslides occurred here in historical time, forming barrier lakes in the Gerby river confluents valleys. The erosion dissection depth here is close to $1000 \mathrm{~m}$. Badzhal lays on the monsoon route, which results in a high level of precipitation here of more than $1000 \mathrm{~mm}$ annually, causing summer river flooding and winter snow avalanches in the mountains. The 
total tension in the central part of the range reaches 10 points also.

Geomorphologic tension, determined by natural forces, on the continental part is the highest in the Taigonos Peninsula and adjacent mountainous ranges (Tumansky, Nenkat), where it reaches 10-12 points. This is a zone of VIII-IX points earthquakes with numerous traces of paleo seismic dislocations. The peninsula itself is limited by faults stretching north-east, located as fault scarps in the relief. Its absolute heights reach $1600 \mathrm{~m}$ and dissection depths reaches 600-800 m. There is up to $1000 \mathrm{~mm}$ precipitation annually on the north-eastern mountainous slopes.

Geomorphologic tension, determined by natural forces, for the Sakhalin Island, which was divided onto 21 regions, fluctuates from 6 to 12 points. Eleven regions are the areas of extremely high tension (10-12 points): the Shmidt Peninsula, the north-western lowland, the West-Sakhalin mountains (excluding the Poyasok land bridge) and the northern and central parts of the East-Sakhalin mountains. The main features are high seismic activity (VIII-IX points), a wide range of dangerous geomorphologic processes, abundance of precipitation (over $1000 \mathrm{~mm} /$ year), and, in the certain parts, dissection deepness (400-800 m) and perennially icy frozen rocks (North-Western lowland).

Within Kamchatka we isolated 48 regions with tension from 7 (Western coast) to 15 (Eastern coast) points. The maximum tension (15 points) is on the Kronotsky and Shipunsky Peninsulas, on the Gamchen and Balaganchik ranges and some parts of the Koryaksky and Kronotsky volcano massifs. These areas have high seismic activity ( $X$ points), abundance of dangerous geomorphologic processes, deep territory dissection (over $800 \mathrm{~m}$ ) and abundance of precipitation (over $1000 \mathrm{~mm}$ / year). Tension is lower (14 points) on the Kronotsky and Avachinsky bay shores and on the Mutnovsky volcano due to decrease of the dissection deepness. This, along with decrease of annual precipitation, reduces the index of geomorphologic tension to 13 points in the Kamchatsky Mys Peninsula, Kamchatsky bay coast, Ilyinskaya and Zheltovskaya volcano massifs and in the Ganalsky range southern part. For the Sredinny range on Kamchatka and the Kumroch, Tumrok, Valaginskii and other ranges, tension is 12 points, which is determined by decrease of seismic activity to IX points in the territory towards the west.

The maximum of naturally determined tension of 16 points (which we determined as potentially catastrophic) is typical of the Kuril Islands - Paramushir, Ketoj, Simushir, Iturup, and Kunashir. A high degree of ecologic-geomorphologic hazard (vast extent of dangerous geomorphologic processes) is combined with high seismic activity (X points), abundance of precipitation (over $1000 \mathrm{~mm}$ / year) and considerably deep relief dissection (altitude difference of up to 1000-1500 m and more). Active volcano presence increases the risk of potential catastrophic processes.

Geomorphologic tension, determined by natural forces, generally varies from 3 to 16 points in the Russian Far East region. The distribution regularities of the zones of naturally determined tension of geomorphologic processes in the Far East region were considered earlier [Gotvansky, Lebedeva, 2010; Lebedeva and others, 2014b]. The results of the study have supported the suggested hypothesis that naturally determined geomorphologic tension (i.e., susceptibility to catastrophic morphogenesis processes) is generally increasing here from the west to the east towards the Pacific ocean: it was estimated at 7-10 points for the Western Okhotsk Sea coast, at 10-12 points for the Sakhalin, at 13-15 points for the Eastern Kamchatka and at 16 points for the Kurils.

Mapping of the Peruvian segment of the Andes (between 5-19 S) that we have conducted (Fig. 2) showed that geomorphologic tension of the region varies from 6 to 16 points. Therefore, the maximum tension of 15-16 points, which we consider as potentially 


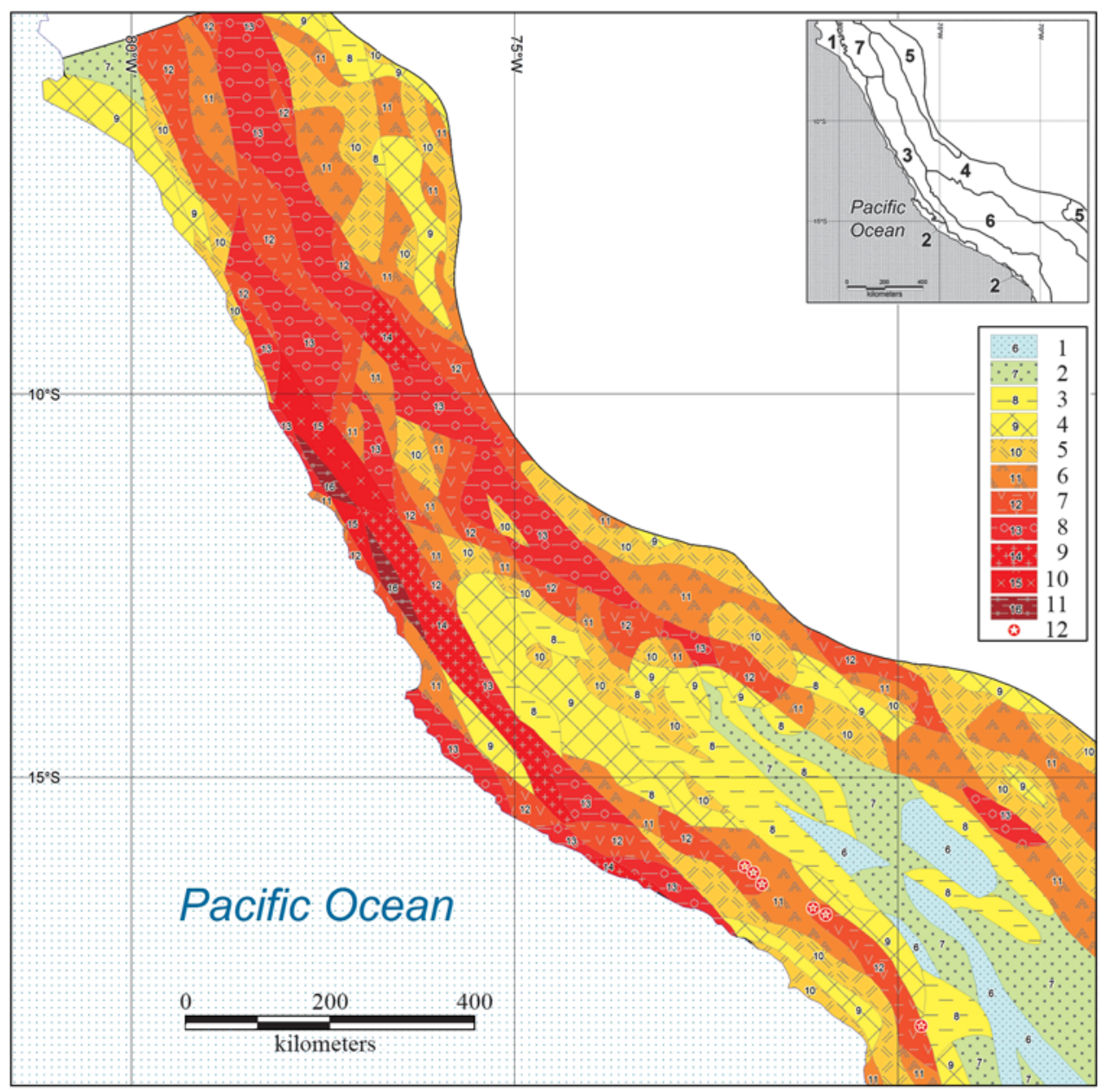

Fig. 2. Map of geomorphologic tension of the Peruvian Andes, scale 1:8 000 000. Legend:

1-11 - natural-determined geomorphologic tension (in points), 12 - active volcanoes.

On inset: orographic zoning elements: 1 - coastal plains, 2 - coast ranges, 3 - Western Cordillera,

4 - Eastern Cordillera, 5 - the Andes eastern branches, 6-Altiplano, 7-Amotape-Chanchan zone.

catastrophic, is typical of the western mega slope of the marginal-continental mountainous system in the interval from $9^{\circ}$ to $13^{\circ} 30^{\prime} \mathrm{S}$ in a strip of up to $100 \mathrm{~km}$ from the coast. This territory is occupied by high (4000 $\mathrm{m}$ and higher) and very deeply dissected ridges and massifs of the Western Cordillera with a wide complex of large scale gravitative and seismic-gravitative processes (rockfalls, talus, landslides, avalanches and others), as well as it is subjected to active erosion and mudflows. This territory includes the river Santa basin, which associates with large catastrophes of the XX century in Uaras town
(1940) and near the foot of the Uascaran massive (1962 and 1970), caused by mass movement of weathering waste under the influence of seismic events.

Southwards from this the most dangerous zone, tension of the western Andes mega slope (Western Cordillera) is estimated at 12-14 points due to a somewhat lesser seismic activity of the territory with the same high and deeply dissected ridges. Tension of geomorphologic settings of the extinct and active volcanoes chain, rimming Altiplano from the south-west, is estimated at 11-12 points. 
Lahars, erosion and badlands forming on fragile volcanites are possible here along with gravitative processes (including debris avalanches).

The northern part of the western Andes mega slope within the studied area is represented by short differently oriented ridges of the Amotape-Chanchan zone with the absolute altitude, dividing ranges, of 600-3000 m with prevailing gravitative and seismicgravitative processes, erosion and mudflows. Geomorphologic settings tension is estimated at 11-12 points.

Tension of 12-14 points were found for coastal densely and deeply dissected ranges with absolute elevations of up to 2500-3000 m. Within low coastal ranges (absolute altitude 200-300 m), tension reaches 12-13 points, and in coastal lowland plains it ranges from 7-9 points in the north to 11-12 in the central part. This variation is due to different seismic activity of the territory.

The Andean Eastern Cordillera in the north of studied territory is represented by block middle and high ridges and massifs, 1000-3000 $\mathrm{m}$ high. Gravitative and seismic-gravitative processes are dominating among dangerous and catastrophic processes and tension varies from 12 to 14 points. Southwards, deeply dissected block high mountainous ridges and massifs prevail (absolute altitude of 2000-4000 m), tension is 11-12 points and more rarely is 13 points. The eastern Andes mega slope also includes adjacent ridgy low-hills (absolute altitude of 500-1500 m) in the northern and the southern parts of the territory with dominance of gravitative and seismic-gravitative processes, fissuring and erosion. Geomorphologic tension of these areas is estimated at 9-11 points.

The central and the southern parts of the Andes axial region is occupied by Altiplano with absolute heights of 3000-4000 m, rimmed by the Western and Eastern Cordillera. In its northern, more dissected part $\left(12^{\circ}-17^{\circ} \mathrm{S}\right)$, erosion with gravitative processes is active and geomorphologic tension is estimated at 8-10 points. In the southern Altiplano, dissection is ten times smaller, plain lands with separate farewell rock massifs prevail and tension is $6-8$ points.

According to the conducted mapping, it has been concluded that potential naturally determined geomorphologic tension of the Peruvian Andes western mega slope, which is the zone of the maximum risk of catastrophic processes, reaches 16 points. For the eastern Andes mega slope, this index is 9-12 points, rarely reaching 13 , and for Altiplano, it ranges within 6-10 points. The important feature of the studied territory is the asymmetric distribution of both geomorphologic processes and geomorphologic settings tension on the Pacific coastal and nearcontinental slopes of the mountainous system.

\section{CONCLUSION}

The compiled maps allowed us to evaluate naturally determined intensity of the extent of geomorphologic processes of the studied regions, associated with geologic-tectonic and physiographic features of the territory, to isolate the potential risk zones and to analyze their location.

Thus, the map of geomorphologic tension can be considered as a stage of study and zoning, which allows selecting areas that are most at risk of unfavorable geomorphologic processes. It is very important for such dynamic, but actively explored regions of continental-margin mountain systems of the Pacific Ocean coast. The proposed method makes it possible, with a sufficient degree of objectivity, to identify territories of potential activation of geomorphologic processes in areas with high depth of erosional dissection, seismic hazard and a wide range of active geomorphic processes.

Comparison of material about two segments of the transitional zones of the Pacific Rim - the north-western and the south-eastern - allows 
Table 2. Geomorphologic parameters and nature factors for geomorphologic tension evaluation: capabilities of small scale and middle scale mapping

\begin{tabular}{|l|l|l|}
\hline \multirow{2}{*}{ Parameters /Factors } & \multicolumn{2}{c|}{ Scale of the map } \\
\cline { 2 - 3 } & $\begin{array}{l}1: 2500000- \\
1: 8000000\end{array}$ & $1: 500000-1: 1000000$ \\
\hline $\begin{array}{l}\text { Relief forming } \\
\text { processes }\end{array}$ & $\begin{array}{l}\text { Ecological-geomor- } \\
\text { phologic hazard, } \\
\text { points }\end{array}$ & $\begin{array}{l}\text { Dominant geomorphic processes spectrum } \\
\text { Catastrophic processes spectrum }\end{array}$ \\
\hline $\begin{array}{l}\text { Features of relief } \\
\text { morphology }\end{array}$ & $\begin{array}{l}\text { Depth of the relief } \\
\text { dissection, } m\end{array}$ & $\begin{array}{l}\text { Depth of the relief dissection } \\
\text { Density of erosion dissection }\end{array}$ \\
\hline $\begin{array}{l}\text { Seismicity hazard } \\
\text { Intensity of shocks, } \\
\text { points }\end{array}$ & $\begin{array}{l}\text { Focuses of earthquakes with a magnitude }>7 \\
\text { Highly seismic zones of linear structures intersection } \\
\text { Active contemporary vertical and horizontal movements }\end{array}$ \\
\hline Precipitation & $\begin{array}{l}\text { Precipitation quantity, } \\
\text { mm per year }\end{array}$ & $\begin{array}{l}\text { Irregularity rainfall during the year } \\
\text { Intensity of precipitation }\end{array}$ \\
\hline $\begin{array}{l}\text { Volcanism } \\
\text { of bedrock }\end{array}$ & - & Active volcanoes \\
\hline
\end{tabular}

confidently identifying common regularities of developing tension of geomorphologic settings of the marginal-continental Pacific Coastal region mountainous systems and isolating the zones of high risk of catastrophic processes: the areas of potential catastrophic processes are located near the edge of the continent in either case.

However, it became obvious that the used mapping scale can hardly consider all factors, which we initially were going to take into account, notably, the density of erosional dissection, types of precipitation, presence of highly seismic zones of linear structures intersection, active contemporary vertical and horizontal movements and others. All these are possible in case of a mediumscale mapping. The next step of further research on geomorphologic tension and forecast estimates of the risk of catastrophic processes is analysis of selected zones of maximum tension at larger scales. We propose [Lebedeva, 2015] to map these potentially the most dangerous sections at a scale of 1:500 000-1:1 000000 considering additional factors listed above (Table 2). As a result, for the key areas identified earlier, regional zones of high geomorphologic tension and potential crises will be delineated on medium-scale maps. The next step is the identification of the most dangerous sections and within these new zones at a large scale (1:100 000).

Such an approach is justified for the selected region because of a considerable length of marginal mountain belts of the Pacific Rim. In the future, it will solve not only applied, but also the fundamental problems - evaluation of geomorphologic tension and distribution of areas of the maximum tension (where the risk of catastrophic processes is the highest) in the mountain systems the Pacific Ocean coast on the whole.

\section{REFERENCES}

1. Alizade E.K. and Tarikhazer S.A. (2015) Ekogeomorfologicheskii risk i opasnosti territorii Bol'shogo Kavkaza (v predelah Azerbaidzhana) (Ecogeomorphologic danger and hazards at Major Caucasus (in the limits of Azerbaijan). Moscow: MAKS Press, 208 p. (in Russian). 
2. Ananyev G.S. (1998) Katastroficheskie protsessy reliefoobrazovanija (Catastrophic relief forming processes). Moscow: MGU. 100 p. (in Russian).

3. Bolysov S.I., Bredikhin A.V., Eremenko E.A. (2015) Geomorfologicheskaya bezopasnost' Rossii (Geomorphologic safety of Russia). Geomorfologicheskie resursy i geomorfologicheskaya bezopasnost': ot teorii k practike / Materialy Vserossi'skoi konferentsii "VII Schukinskie chtenija" (Geomorphologic resources and geomorphologic safety: from theory to practice. VII Schukin Conference: Extended abstracts) M.: MAKS Press. 11-16 pp. (in Russian)

4. Conozcamos los peligros geologicos en la region Andina/ Servicio Nacional de Geologia y Mineria. (2007) Publication Geologica Multinacional. N 5. 78 p.

5. Corominas J. (2008) Guidelines for landslide susceptibility hazard and use planning / Engineering Geology. DOI: 10.1016/j.enggeo.2008.03.022

6. Gorelov S.K. (2008) O probleme ecologo-geomorfologicheskogo kartirovanija (na primere territorii Severnoi Evrazii) (On the problem of ecologic-geomorphologic mapping (the Northern Eurasia as an example)) // Geomorfologiya, N 2: 61-66. (in Russian with English summary).

7. Gotvansky V.I. and Lebedeva E.V. (2010) Vlijanie prirodnyh i antropogennyh faktorov na napriazhionnost' geomorfologicheskih protsessov na Dal'nem Vostoke (Natural and anthropogenic factors influence on geomorphologic processes intensity in the Far East) // Geomorfologiya, N 2: 26-36. (in Russian with English summary)

8. Kozlova A.E., Lokshin G.P., and Chesnokova I.V. (2005) Karta rajonirovanija territorii Rossii po stepeni ekstremal'nosti razvitija ecologo-geomorfologicheskih protsessov (Map of zoning of the territory of Russia on the degree of extreme ecologic-geomorphologic situation). Scale 1:9000 000. M.: IG RAN.

9. Lebedeva E.V. (2013a) Prirodnye i tehnogennye predposylki napriazhionnosti geomorfologicheskih protsessov And (Natural and anthropogenic basis of geomorphologic processes intensity in the Andes) // Geomorfologiya, N 4: 48-61 (in Russian with English summary)

10. Lebedeva E.V. (2013b) Printsypy sostavlenia karty napriazhionnosti geomorfologicheskih protsessov okrainno-kontinental'nyh gornyh system Dal'nego Vostoka (The foundation of the map on intensity of geomorphologic processes of the Far East continental margin mountain belts). // Geomorfologiya i kartografija. Materialy XXXШ plenuma Geomorfologicheskoi Komissii RAN (Geomorphology and Cartography: Proceed. of XXXIII plenum of Geomorphological Commission RAS). Saratov: SGU. 507-511 pp. (in Russian)

11. Lebedeva E.V. (2015) Napriazhionnost' geomorfologicheskih obstanovok okrainnokontinental'nyh gornyh system Pritihookeanija (Tension of geomorphologic conditions of the marginal -continental mountain belts of the Pacific Ocean coast). Geomorfologicheskie resursy i geomorfologicheskaya bezopasnost': ot teorii k practike / Materialy Vserossi'skoi konferentsii "VII Schukinskie chtenija” (Geomorphologic resources and geomorphologic safety: from theory to practice. VII Schukin Conference: Extended abstracts) M.: MAKS Press. 129-132 pp. (in Russian) 
12. Lebedeva E.V., Mikhalev D.V., Novoa J.E., and Kladovschikova M.E. (2014a) Geomorphological hazard and disasters in the South American Andes" /Geography. Environment. Sustainability, N 1: 80-98.

13. Lebedeva E.V., Mikhalev D.V., and Shvarev S.V. (2015) Geomorfologicheskaya napriazhionnost' tsentral'nogo sektora gornoi sistemy And (Geomorphologic tension of the Central Andes) // Geomorfologiya, N 2:77-88. (in Russian with English summary)

14. Lebedeva E.V., Shvarev S.V., and Gotvansky V.I. (2014b) Prirodno-obuslovlennaja napriazhionnost' geomorfologicheskih protsessov territorii Dal'nego Vostoka Rossii (Naturally determined geomorphologic processes tension of the Russian Far East territory) / Geomorfologiya, N 4: 48-59 (in Russian with English summary)

15. Liang W.J., Zhuang D.F., Jiang D., Pan J.J., and Ren H.Y. (2012) Assessment of debris flow hazard using a Bayesian Network. Geomorphology, v. 171-172: 94-100.

16. Simonov Y.G. (1997) Ball'nye otsenki v prikladnyh geograficheskih issledovanijah I puti in sovershenstvovanija (Scoring in applied geographical studies and its development). Vestnik MGU, ser. 5. geogr., N 4: 7-10 (in Russian with English summary).

17. Karta sovremennoi dinamiki reliefa Severnoi Evrazii (The map of current relief dynamics of North Eurasia). (2003) Scale 1:5 000 000. M.: IG RAN.

18. Karta "Stepen' ecologo-geomorfologicheskoi opasnosti sovremennyh reliefoobrazujuschih protsessov" (The map "The ecologic-geomorphologic hazard level of contemporary relief-forming processes") (2006) Scale 1:8 000 000. M.: IG RAN.

19. Timofeev D.A. and Bylinskaya L.N. (1987) Karta otsenki erosionnoi opasnosti territorii SSSR (USSR map of erosion hazard evaluation)/ Erosionnye I ruslovye protsessy $\vee$ razlichnyh prirodnyh uslovijah (Erosion and river bed processes in different natural conditions). Moscow: MGU. 24-25 pp. (in Russian).

20. Ulomov V.I. (2013) Obschee seismicheskoe zonirovanie territorii Rossiiskoi Federatsii (The General Seismic Zoning of the territory of Russian Federation) // Problemy ingenernoi seismologii, v. 4, N 4: 5-20 (in Russian)

21. http://eros.usgs.gov

22. http:// gmo.gfz-potsdam.de

23. http://www.esrl.noaa.gov 


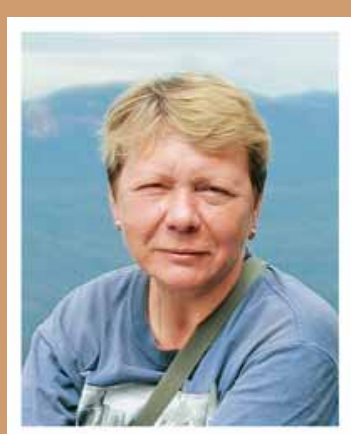

Ekaterina V. Lebedeva is Senior Researcher of the Laboratory of Geomorphology, the Institute of Geography, RAS, and Executive Secretary of the editorial board of the journal "Geomorphology". She graduated from the Lomonosov Moscow State University and received her Ph. D. degree in 1992. The area of her scientific interest: relief evolution in the changing natural conditions and under the influence of anthropogenic factors, intensity of geomorphologic processes, relief of volcanic regions, ecologicgeomorphologic problems. Regions of Research: Russian Far East, South and East Africa, South and Central America, Australia. She is the author of about 100 scientific papers.

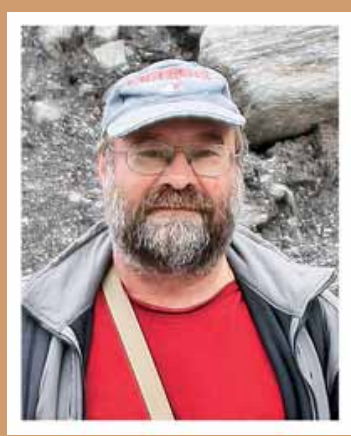

Dmitry V. Mikhalev is Senior Researcher of the Laboratory of Geoecology of the North, Lomonosov Moscow State University. He received his Ph. D. degree in 1990. The area of his scientific interest: isotope geocryology, paleogeography, paleoclimatology, cryogenic processes, geoecology. Regions of Research: Russian Arctic, South and East Africa, South and Central America, Australia. He is the author of about 70 scientific papers.

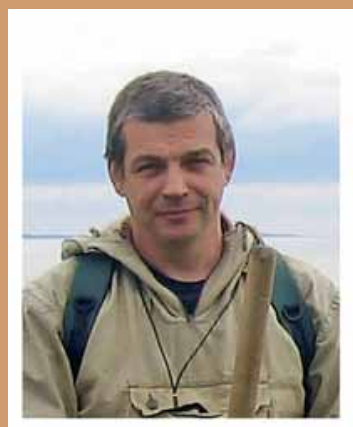

Sergey V. Shvarev graduated from the Geomorphology Department of the Faculty of Geography, Lomonosov Moscow State University in 1986. He received his Ph. D. degree in geoecology from the Moscow University of Geodesy and Cartography in 2006. He is Lead Researcher at the Laboratory of Geomorphology of the Institute of Geography, RAS, and Research Fellow (part time) at the Schmidt Institute of Earth Physics, RAS. The areas of his scientific interests include exogenic processes, geotechnical systems, natural-techogenic disasters, morphotectonics, paleoseismology and neotectonics. He has participated in scientific field expeditions in different regions of Eurasia. He is the author (co-author) of five monographs, and about 100 papers in journals and conference proceedings.

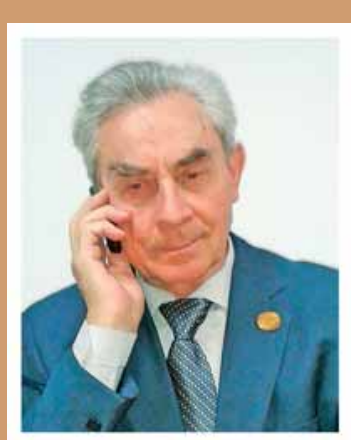

Veniamin I. Gotvansky is Senior Researcher; he received his Ph.D. degree in geography. He has been a member of the Russian Geographical Society since 1957. He worked for many years in the Far East of Russia. Not only problems of geomorphology but also ecology are in the focus of his research; for example, preservation of watercourses of the Amur River basin is under his special attention 